GEOLOGICA BALCANICA 50 (1), Sofia, April 2021, pp. 3-9.

\title{
Fossil gastropods Campanile lachesis Bayan, 1870 from the upper Eocene of the Eastern Rhodopes (Bulgaria)
}

\author{
Lidiya Kirilova ${ }^{1}$, Ivan Ivanov ${ }^{2}$ \\ ${ }^{1}$ Regional Museum of History Kardzhali, 4 Republikanska Str., 6600 Kardzhali, Bulgaria; e-mail: lidiak@gbg.bg \\ ${ }^{2}$ GORUBSO Kardzhali AD, 83 Republikanska Str., 6600 Kardzhali, Bulgaria; e-mail: iv1960@abv.bg
}

(Accepted in revised form: February, 2021)

\begin{abstract}
The subject of this study is the description of eight specimens of fossil gastropods Campanile lachesis Bayan, 1870, family Campanilidae, from the fund of the Regional Museum of History in Kardzhali. They were found in the area of the village of Gorna Krepost, Kardzhali Municipality, at the eastern foot of the Archeological Complex Perperikon, in the upper Eocene (Priabonian) limestone layers of the so-called Beli Plast Rhyodacite Complex. The paleoecological traits of the present fauna give ground to infer that this was a very shallow reefal environment with a rocky substrate sandy bottom, overgrown with algae, and the water was warm, with normal salinity.
\end{abstract}

Kirilova, L., Ivanov, I. 2021. Fossil gastropods Campanile lachesis Bayan, 1870 from the upper Eocene of the Eastern Rhodopes (Bulgaria). Geologica Balcanica 50 (1), 3-9.

Keywords: gastropod Campanile lachesis, family Campanilidae, upper Eocene, Eastern Rhodopes.

\section{INTRODUCTION}

Representatives of the genus Campanile, family Campanilidae, are giant sea gastropods with a stout, high-spiral, tower-like shell, which can reach over $60 \mathrm{~cm}$ in length and can contain more than 30 whorls (Taylor and Lewis, 2005). The genus has a stratigraphical range from the Upper Cretaceous (Maastrichtian) to the present day. It is best known from the Eocene of the Paris Basin, where well-preserved finds of Campanile giganteum Lamarck, 1804, up to a meter long, have been found (Squires, 1993). These specimens, along with some from Jamaica, are among the largest gastropods to have ever existed on Earth (Squires, 1993). During the Paleogene, the genus Campanile underwent a wide geographical expansion (Squires, 1993). It was widespread in the Eocene, with numerous records from North and South America, the Caribbean, Europe, Africa, and Asia, as far east as Japan (Salgeback and Savazzi, 2006). According to Jung (1987), the peak of diversity and distribution of the genus Campanile in Europe was reached during the middle Eocene. After the Oligocene, the genus disappeared from Eurasia and withdrew to the east-southeast (ibid.). After the middle Eocene, there has been a sharp worldwide decline in Campanile species diversity. Neogene and Pleistocene finds are scarce, and the single surviving species today is Campanile symbolicum Iredale, 1917 (Squires, 1993).

The reason for the sharp post-Eocene decline in species diversity of the genus Campanile is still unknown. Houbrick (1981) proposed two hypotheses, although both of them have been criticized. 
According to this author, there was trophic competition between the gastropods of Campanilidae and Strombidae, as the members of both families fed upon algae. He opined that Campanilidae ended up losing in this competitive relationship. As a second possible reason for the disappearance of Campanilidae from the Mediterranean region, he pointed out the Messinian Salinity Crisis. However, this event is unlikely to be connected, as Campanilidae withdrew from the region at the end of the Oligocene, about 17 Ma before the Messinian Salinity Crisis (Jung, 1987).

The single surviving species of the genus, Campanile symbolicum Iredale, 1917, lives in large populations on sandy patches between rocks in depths of $1 \mathrm{~m}$ to $4 \mathrm{~m}$ along the southwestern coast of Australia (Squires, 1993). This is a subtidal algal feeder, creeping on both rocky substrate and soft sediments. Unlike its Eocene predecessors, it reaches a maximum length of $24.4 \mathrm{~cm}$ (Houbrick, 1981). When living on sandy bottom, it either lies half-buried into the sediments or drags its shell through the topmost layer of sediment, leaving behind a deep furrow. The largest species of Campanile from the Eocene of Southern Europe inhabited a shallowwater nearshore environment. Recorded fossil finds indicate that they lived in an environment similar to that of modern-day C. symbolicum (Salgeback and Savazzi, 2006).

The aim of the present study is to describe and illustrate a fossil material of the genus Campanile from the fund of the Regional Museum of History in Kardzhali (Bulgaria). Despite being small in number, this material is a valuable addition to the previously obtained evidence of campanilid gastropods from Bulgaria and Europe.

\section{GENUS CAMPANILE IN BULGARIA}

In 1896, Stefan Bontscheff described the "Tertiary" Basin of the Haskovo region (SW Bulgaria) and made one of the first geological maps of this area. Among the fossils, which he found, a new species, Cerithium haskovense collected from a locality near the city of Haskovo was defined (Bontscheff, 1896). Bontscheff described the species in detail, identifying it as most closely related to C. giganteum Lam. and C. parisiense Desh. of the Paris Ba$\sin$, but pointing out that it differs from the French forms by the shape and the location of the tubercles on the whorls. Later, Oppenheim (1901) revised Bontscheff's taxonomic determination, claiming that Cerithium haskovense matches Cerithium lachesis Bayan, 1870 in all aspects, but differs from C. parisiense in having fewer and slightly differently shaped tubercles. Gochev (1930) concurred with Oppenheim's (1901) opinion that C. haskovense is a synonym of $C$. lachesis and found out that another specimen from Bonchev's collection, identified as C. parisiense Desh., should also be interpreted as belonging to $C$. lachesis Bayan. Karagyuleva (1964) made a detailed characterization of the genus Campanile, including C. lachesis, and recorded a new Bulgarian locality, Chengene skele (Burgas Municipality). The latter author dated the known Bulgarian Campanile occurrences as late Eocene (Priabonian). Recently, Matsubara (2009) also opined that Cerithium haskovense and Campanile lachesis are synonyms.

\section{GEOLOGICAL SETTING, LOCALITY AND MATERIAL OF THIS STUDY}

The Rhodope Massif forms the innermost part of the Balkanides, extending over large areas of South Bulgaria. During the Late Cretaceous-Eocene, the Rhodope Massif encompassed intense processes of extension (Ivanov, 2000). As a result, huge meta-
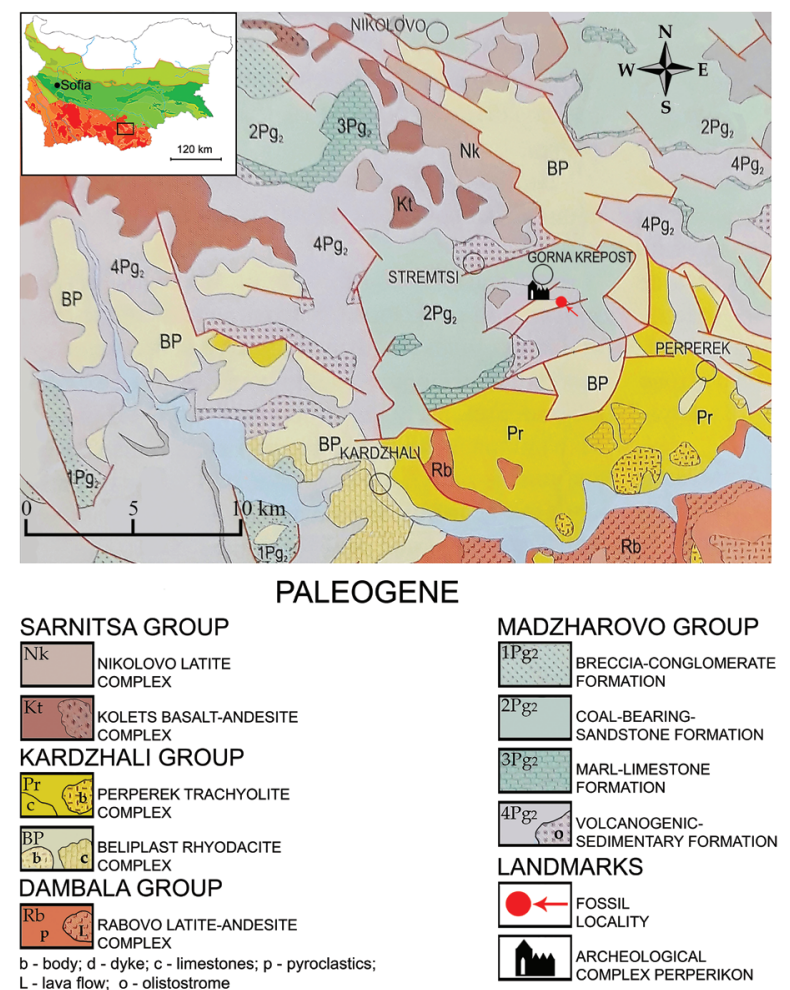

Fig. 1. Geological map of the locality, from which the gastropods of this study were obtained (after Georgiev, 2012). 
morphic core complexes (domes) were formed, separated by large depressions. The examined fossils were found within the inner parts of the East Rhodope complex depression (Georgiev, 2012; equivalent to the East Rhodope Paleogene depression of Ivanov, 1960). During the Eocene and Oligocene, this depression represented a shallow sea basin and an area of intense sedimentation and abundant volcanic activity. The sedimentary rocks are mainly located at the lower part of the overall stratigraphic section, whereas the upper part is predominantly composed of acid to intermediate volcanic rocks.

The fossils that are a subject of this study were collected from the area of the village of Gorna Krepost, Municipality of Kardzhali, at the eastern foot of the Archeological Complex Perperikon (N41.715528' ; $25.472771^{\circ}$ ) (see Fig. 1). They were found in limestone layers of the so-called Beli Plast Rhyodacite Complex (Georgiev, 2012). The limestones are 2-3 m thick and are intercalated with tuffs and tuffites. They crop out to the east of the summit, upon which the Archeological Complex Perperikon is situated, in the scarps of the newly constructed road. The age of these limestones is determined as Priabonian (Boyanov et al., 1990).

\section{SYSTEMATIC PALEONTOLOGY}

The classification of Bouchet and Rocroi (2005) is adopted herein.

\section{Class Gastropoda Cuvier, 1797}

Clade Sorbeoconcha Ponder and Lindberg, 1997

Superfamily Campaniloidea Douvillé, 1904

Family Campanilidae Douvillé, 1904

Genus Campanile Bayle in: Fischer, 1884

Type species. Cerithium giganteum Lamarck, 1804, middle Eocene, Paris Basin.

\section{Campanile lachesis Bayan, 1870a}

(Fig. 2a-c)

1870a. Cerithium Lachesis Bayan, p. 478.

1870b. Cerithium Lachesis Bayan: Bayan, p. 33, Pl. 4, Fig. 2; Pl. 5, Fig. 2.

1896. Cerithium Haskovense Bontscheff, p. 381, Taf. 6 (4), Fig. 7.

1896. Cerithium Lachesis Bayan: De Gregorio, p. 75, Taf. 10, Figs 1-4.

1901. Cerithium (Campanile) lachesis (Bayan): Oppenheim, p. 271, Taf. 15(5), Fig. 34.

1905. Cerithium (Campanile) lachesis (Bayan): Dainelli, pp. 46-50, Pl. 1, Figs 9-11.

1911. Campanile lachesis (Bayan): Boussac, pp. 284-285, Pl. 17, Fig. 52a.

1930. Campanile lachesis (Bayan): Gochev, pp. 27-28, Taf. 1, Fig. 3, Taf. 5, Fig. 1.

1958. Campanile lachesis (Bayan): Temkova, p. 113.

1964. Campanile lachesis (Bayan): Karagyuleva, p. 154, Pl. 41, Fig. 1.

Type. Data for the type specimen is not given.

Diagnosis. A very large species, closely related to Cerithium parisiense Desh. It is distinguished by its more voluminous shape, the tubercles of the adult are sharper and shorter, and by the number of granular ribs of the juvenile (6-7), which persist much later than in the C. parisiense (Bayan, 1870a). Subchannel suture. Two-folded columella (ibid.).

Material and record. Eight gastropod specimens hosted at the Regional Museum of History in Kardzhali (Inv. Nrs Kp 409 - Kp 415, Kp 417, original abbreviation of the inventory numbers in Cyrillic is “К $\Pi$ ”), found near the village of Gorna Krepost, Kardzhali Municipality.

Dimensions. See Table 1.

Description and discussion. The shell is very large to gigantic, highly-conical (pleural angle $20^{\circ}-24^{\circ}$ ), with a spiral sculpture of 9 whorls in the most com-

Table 1

Dimensions of studied fossil specimens

\begin{tabular}{ccccc}
\hline Inventory Nr & $\begin{array}{c}\text { Number of whorls } \\
\text { preserved }\end{array}$ & Length (mm) & $\begin{array}{c}\text { Diameter of the widest } \\
\text { whorl section (mm) }\end{array}$ & Pleural angle \\
\hline Kp 409 & 3 & 150 & 110 & $20^{\circ}$ \\
Kp 410 & 2.5 & 170 & 140 & $20^{\circ}$ \\
Kp 411 & 2.5 & 190 & 140 & $24^{\circ}$ \\
Kp 412 & 3 & 210 & 120 & $20^{\circ}$ \\
Kp 413 & 2.5 & 170 & 120 & $20^{\circ}$ \\
Kp 414 & 3 & 170 & 130 & $20^{\circ}$ \\
Kp 415 & 5 & 270 & 140 & $24^{\circ}$ \\
Kp 417 & 9 & 330 & 120 & $24^{\circ}$ \\
\hline
\end{tabular}


plete specimen - Kp 417 (Fig. 2a; Table 1). The last whorl is significantly larger than the others, with a prominent base. The aperture is rounded quadrangular, with a narrow, long, oblique and slightly backwardly curved siphonal canal. The outer labium is fanned and sharp. The columella has two folds, which are seen in specimen Kp 411 (Fig. 2b). Each whorl consists of two parts: a lower, barely convex one; and a flat, even slightly concave, upper one. The lower (or rather the middle) part is ornamented with 10 to 11 big tubercles (specimen Kp 410) (Fig. 2c).

Unfortunately, the most complete specimen Kp 417 (330 $\mathrm{mm})$, is an internal mold, in which the relief and ornamentation of the shell are missing. However, these can be found on some of the other samples, especially Kp 410, where the tubercles on the last few whorls can easily be counted.

Fossil gastropods preserved as molds are found very often in the geological record since their shells are built of aragonite, which makes them prone to dissolution during the fossilization process (Taylor and Lewis, 2005). In the genus Campanile, much of the early whorls are secondarily thickened and sealed off by septa. Because of this, the internal molds of the large campanilids are substantially shortened, compared to the original shells, and their apices are rounded into unusually large (up to 20 $\mathrm{mm}$ in diameter) protoconchs, resembling hemispheres, which correspond to the inner surface of the last septum (Salgeback and Savazzi, 2006).

According to Karagyuleva (1964), C. lachesis is closely related to $C$. giganteum, but differs by the outline of the whorls, as well as the arrangement of the tuberculation. The tubercles in C. lachesis can be found on the lower half of the whorls, whereas in C. giganteum they are situated on the upper whorls and have a different shape. According to other authors, the tubercles in C. lachesis are located not on the lower, but on the middle part of the whorls (Harzhauser et al., 2013).

Paleoecological notes. The site, at which the fossils were found, strongly resembles that at Posušje, Western Herzegovina, where a remarkably wellpreserved coral reef, with fossil macrofauna including Campanile lachesis Bayan, 1870 and other species of the genus Campanile, were found in Paleogene (middle Eocene) sediments. It is assumed that these gastropods fed upon the detritus of coral reefs (Glamuzina, 2015). In our case, near the village of Gorna Krepost, parts of large coral structures and red algae of the genus Corallina can be observed
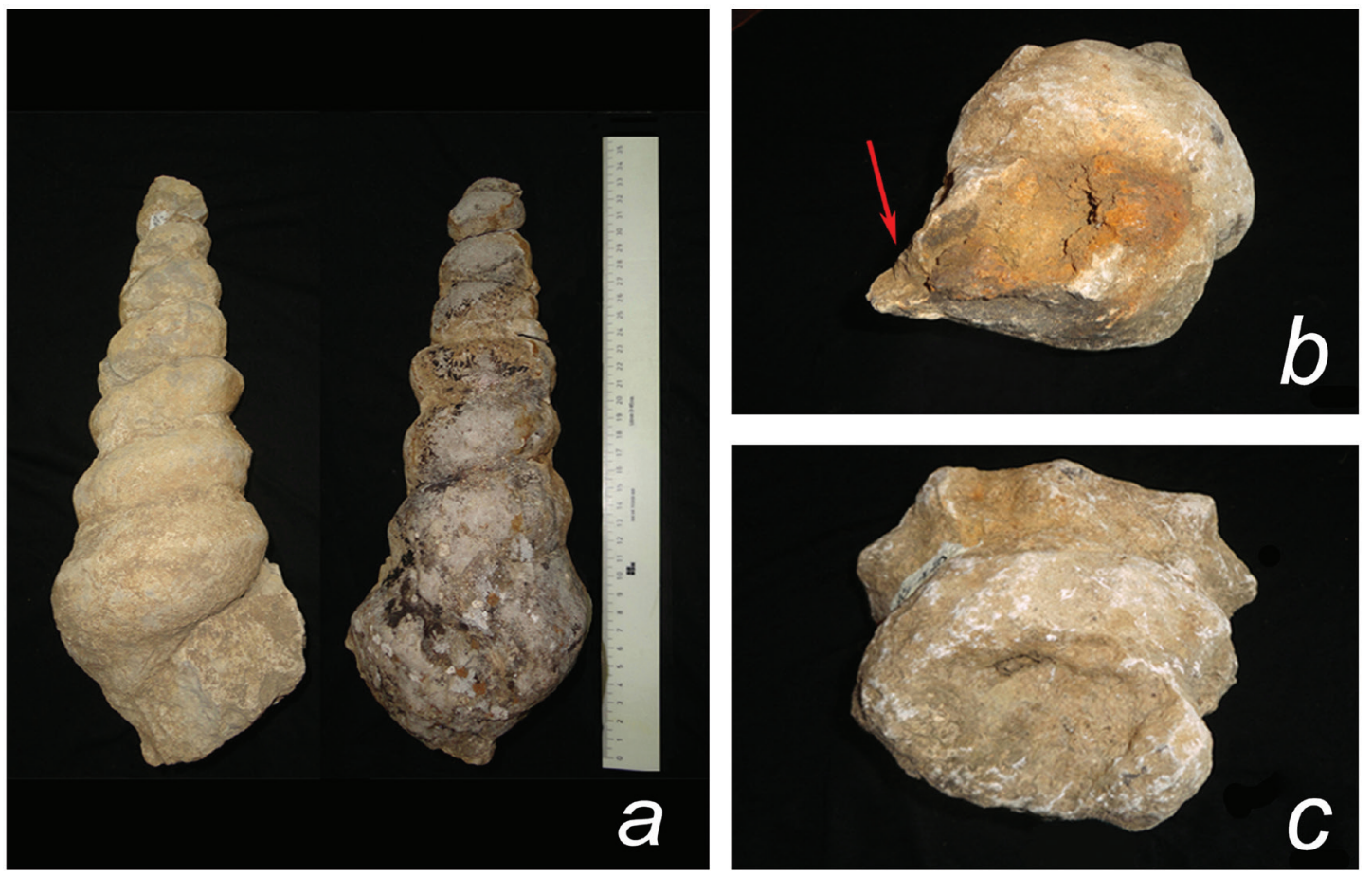

Fig. 2. Campanile lachesis Bayan, 1870 from the late Eocene (Priabonian) near the village of Gorna Krepost, Eastern Rhodopes, Bulgaria: a) high-conical spiral structure of 9 whorls in specimen $\mathrm{Nr} \mathrm{Kp} \mathrm{417;} \mathrm{b)} \mathrm{columella} \mathrm{with} \mathrm{two} \mathrm{folds} \mathrm{in} \mathrm{specimen} \mathrm{Nr} \mathrm{Kp} \mathrm{411;}$ c) ornament of large tubercles on the last whorls in specimen $\mathrm{Nr} \mathrm{Kp} 410$. 
in the field. In addition to Campanile, fossil gastropods of the genera Velates, Conus and Euspira, as well as accompanying bivalves of the genera Pecten and Venus and giant foraminifers of the genus Discocyclina, also occur. Based on the described fossil assemblage, we could conclude that the studied region was a part of an ancient sea with shallow reefal environment, a sandy-stony bottom, overgrown with algae, and the water was warm, with normal salinity.

Occurrence. As previously mentioned, Campanile lachesis was first recorded from the Eocene near Roncá township, Veneto region, Northeastern Italy (Bayan, 1870a, b). It was reported from the same area, but more accurately dated as middle Eocene, by De Gregorio (1896). The species is known from a few localities of the Eocene near Tribistovo, Konjovac and Posušje (Oppenheim, 1901; Sremac et al.,
2014, Glamuzina, 2015), as well as from the middle Eocene near Lukavac and the Bartonian-Priabonian strata near Zagorje (Soklić, 2019), Bosnia and Herzegovina. It is documented in the Eocene near Ostrovica, Žažvić and Bribir, Croatia (Dainelli, 1905; Milan, 1956), as well as in the upper Eocene of La Palarea, France (Boussac, 1911) and the Dragozel region, Republic of North Macedonia (Temkova, 1958). Campanile lachesis was also recorded in the middle Eocene of Central Anatolia, Turkey (Haymana region) (Deveciler and Taner, 2008), and the middle to upper Eocene of North Africa and Romania (Transylvania) (Deveciler and Taner, 2008). In addition, it was also found in an Eocene flysch succession in Western Slovenia (Mikuž et al., 2013) and the middle to upper Eocene of Central Catalonia (Sant Salvador de Guardiola), Spain (Alcalá and Mampel, 2014) (Fig. 3).

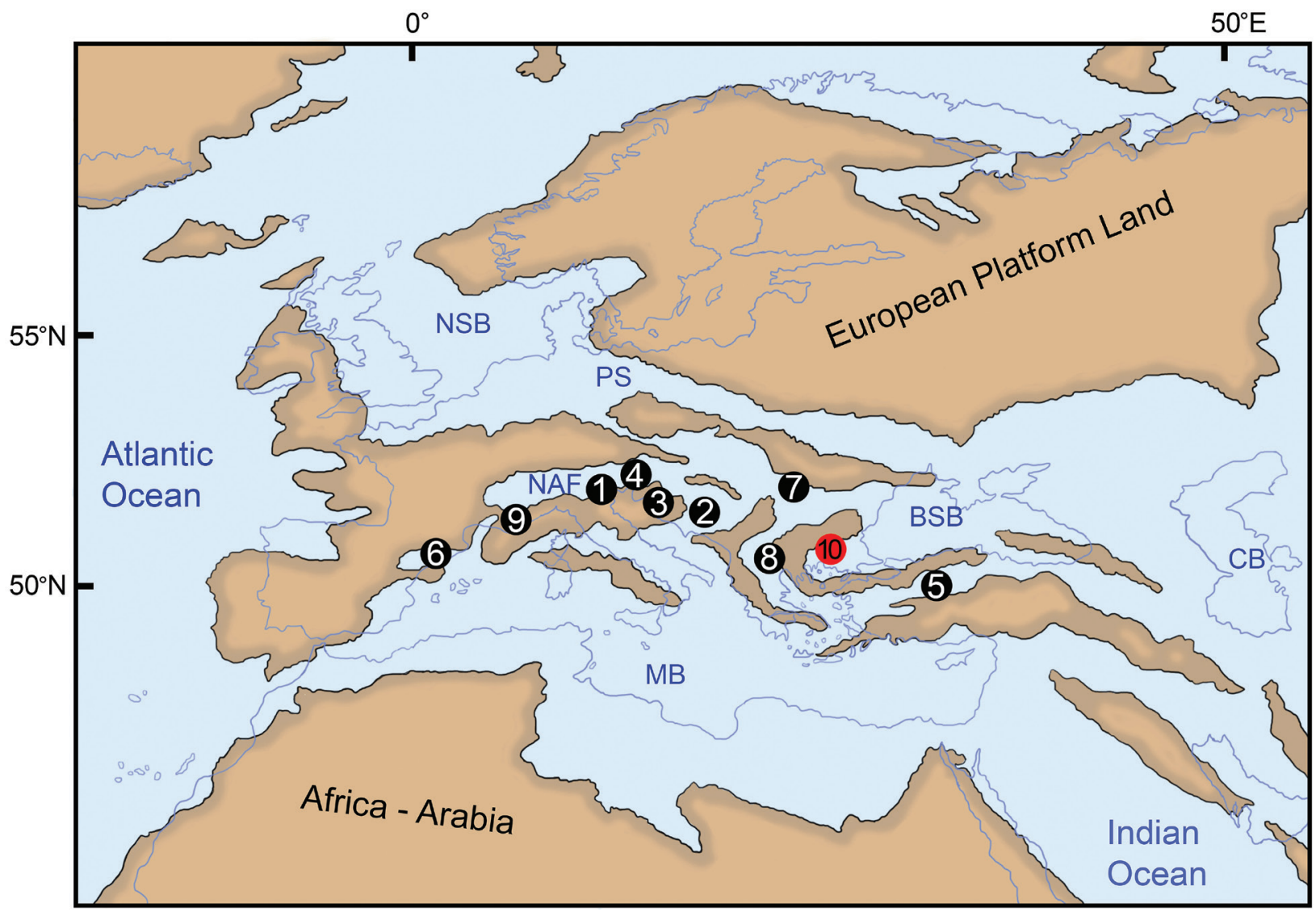

Fig. 3. Paleogeographic map (middle-late Eocene; after van Der Boon et al., 2019) showing the main fossil localities of Campanile lachesis: 1) Italy (Roncá) - middle Eocene; 2) Bosnia and Herzegovina (Tribistovo, Konjovac, Posušje - Eocene; Lukavac - middle Eocene; Zagorje - middle-late Eocene); 3) Croatia (Ostrovica, Žažvić, Bribir) - Eocene; 4) Western Slovenia (Eocene); 5) Turkey (Haymana region) - middle Eocene; 6) Spain (Central Catalonia) - middle-late Eocene; 7) Romania (Transylvania) - middle-late Eocene; 8) Republic of North Macedonia (Dragozel region) - late Eocene; 9) France (La Palarea) - late Eocene; 10) Bulgaria (Haskovo; Chengene skele, Burgas; Gorna Krepost, Kardzhali) - late Eocene.

BSB - Black Sea Basin; MB - Mediterranean Basin; CB - Caspian Basin; PS - Polish Strait; NSB - North Sea Basin; NAF - North Alpine Foreland Basin. 
Eight fossil gastropod specimens, Priabonian in age, from the fund of the Regional Museum of History in Kardzhali were identified and described as Campanile lachesis. After the site near Haskovo and the one near Chengene skele, Burgas Municipality, the locality of fossil specimens of Campanile lachesis at the village of Gorna Krepost is the third registered in Bulgaria and a new field of upper Eocene campanilid gastropods in Europe. These finds, together with specific assemblage of gastropods, bivalves and large foraminifers, indicate shallow reefal environment with sandy-stony bottom, warm water and normal salinity.

\section{Acknowledgements}

The authors are indebted to Prof. Jasenka Sremac (University of Zagreb, Croatia) and Dr Slaveya Petrova (University of Plovdiv, Bulgaria) for useful critical reviews of the manuscript.

\section{REFERENCES}

Alcalá, L., Mampel, L. 2014. Wonders of Ancient Life. Fossils from European Geoparks. Fundación Conjunto Paleontológico de Teruel-Dinopolis, Teruel, 156 pp.

Bayan, F. 1870a. Sur les terrains tertiaires de la Vénétie. Bulletin de la Société Géologique de France 27, 444-486.

Bayan, F. 1870b. Études faites dans la collection de l'École des Mines sur des fossiles nouveaux ou mal connus. F. Savy, Libraire de la Société Géologique de France, Paris, 164 pp., 20 pls., https://doi.org/10.5962/bhl.title.160063.

Bontscheff, S. 1896. Das Tertiärbecken von Haskovo (Bulgarien). Jahrbuch der Kaiserlich Königlichen Geologischen Reichsanstalt Wien 46 (2), 309-384, pls. III-IV.

Boyanov, I., Kozhoukharov, D., Goranov, A., Yanev, Y., Shilyaphova, Z., Ruseva, M. 1990. Geological map of Bulgaria 1:100 000, Iskra map sheet. Committee on Geology and Mineral Resources, Sofia.

Bouchet, P., Rocroi, J.-P. 2005. Classification and nomenclature of gastropod families. Malacologia 47 (1-2), 1-397.

Boussac, J. 1911. Études paléontologiques sur le Nummulitique alpin, Mémoires pour servir à l'explication de la carte géologique détaillée de la France. Ministère des Travaux Publics, Imprimerie Nationale, Paris, 437 pp., Atlas (4 pp.text, 52 pls.).

Dainelli, G. 1905. La fauna eocenica di Bribir in Dalmazia. Parte II. Palaeontographia Italica: Memorie di paleontologia 11, 1-92.

De Gregorio, A. 1896. Monografia della fauna eocenica di Roncà con un'appendice sui fossili di Monte Pulli. Annales de géologie et de paléontologie 21, 163 pp.

Deveciler, A.Y., Taner, G.T.D. 2008. Haymana çevresindeki eosen yaşlı Çayraz formasyonu pelecypoda ve gastropoda fauna larının paleontolojisi. Yüksek Lisans Tezi, Ankara Üniversitesi, 70 pp.

Georgiev V. 2012. Metallogeny of the Eastern Rhodope. "Professor Marin Drinov" Academic Publishing House, Sofia, 262 pp. (in Bulgarian, with English abstract).

Glamuzina, G. 2015. Eocenski koraljni greben s najvecim izumrlim puzevima na svijetu - Campanile gigantea Lamarck na Boksitonosnim erenima kod Posusja u Zapadnoj Hercegovini. Rudarsko-geološki glasnik 19, 150-169.

Gochev, P. 1930. Revision und Ergänzung der alttertiären Fauna von Haskovo. II. Mollusca. Review of the Bulgarian Geological Society 2 (3), 17-40 (in Bulgarian and German).
Harzhauser, M., Hosgor, I., Pacaud, J.M. 2013. Thanetian gastropods from the Mesopotamian high folded zone in Northern Iraq. Paläontologische Zeitschrift 87(2), 179-199, https://doi.org/10.1007/s12542-012-0155-z.

Houbrick, R. 1981. Anatomy, biology and systematics of Campanile symbolicum with reference to adaptive radiation of the Cerithiaceae (Gastropoda: Prosobranchia). Malacologia 21 (1-2), 263-289.

Ivanov, R. 1960. Magmatismus in der paläogenen Depression der östlichen Rhodope. Teil 1. Travaux sur la géologie de la Bulgarie, série Géochimie et minéraux 1, 312-387 (in Bulgarian, with German abstract).

Ivanov, Z. 2000. Tectonic position, structure and tectonic evolution of the Rhodope massif. In: Guide to Excursion $A B C D$ - GEODE 2000, Workshop, Borovets, Bulgaria, 1-6.

Jung, P. 1987. Giant gastropods of the genus Campanile from the Caribbean Eocene. Eclogae Geologicae Helvetiae 80 (3), 889-896.

Karagyuleva, Y. 1964. Les fossiles de Bulgarie. VIa. Paléogène Mollusques. Académie bulgare des Sciences, Sofia, 270 pp. (in Bulgarian, with French abstract).

Matsubara, T. 2009. A checklist of species-group names of Cenozoic Campanile (Gastropoda: Campanilidae). Paleontological Research 13 (3), 285-292, https://doi. org/10.2517/1342-8144-13.3.285.

Milan, A. 1956. Prilog poznavanju eocenske faune molusaka sjeverne Dalmacije. Geoloski vjesnik 10, 57-69 (in Croatian, with German abstract).

Mikuž, V., Čvorović, B., Bartol, B. M. 2013. Nekaj mehkužcev iz eocenskega fliša Goriških brd, Western Slovenia. Folia biologica et geologica 54 (1), 47-94 (in Slovenian, with English abstract).

Oppenheim, P. 1901. Über einige alttertiäre Faunen der Österreichisch-Ungarischen Monarchie. (Zweiter Theil. Tafel XI-XIX und Textillustration 13-18). Beiträge zur Paläontologie und Geologie Österreich-Ungarns und des Orients 13, 185-277.

Salgeback, J., Savazzi, E. 2006. Constructional morphology of cerithiform gastropods. Paleontological Research 10 (3), 233-259, https://doi.org/10.2517/prpsj.10.233.

Soklić, I. 2019. Fossil Flora and Fauna of Bosnia and Herzegovina. Academy of Sciences and Arts of Bosnia and Herzegovina, Sarajevo, $861 \mathrm{pp}$. 
Squires, R. 1993. New reports of the large gastropod Campanile from the Paleocene and Eocene of the Pacific coast of North America. The Veliger 36(4), 323-331.

Sremac, J., Makovec-Bosnjak, M., Prlj-Simic, N., Glamuzina, G., Mikulic, I. 2014. Eocenska marinska makrofauna podrucja Imotski-Ričice-Tribistovo: paleontoloski dragulj i geoturisticki “as u rukavu”. Rudarsko-geološki glasnik 18, 121-134 (in Croatian, with English abstract).

Taylor, P., Lewis, D. 2005. Fossil Invertebrates. Harvard University Press, Cambridge, Massachusetts, 208 pp.

Temkova, V. 1958. Paleontološka obrabotka na faunata vo
Tikveškiot basen i okolinata (urgon, priabon, neogen i pleistocen). Trudovi na Geološkiot zavod na Narodna Republika Makedonija 6, 93-126.

van Der Boon, A., van der Ploeg, R., Cramwinckel, M.J., Kuiper, K.F., Popov, S.V, Tabachnikova, I.P., Palcu, D.V., Krijgsman, W. 2019. Integrated stratigraphy of the EoceneOligocene deposits of the northern Caucasus (Belaya River, Russia): Intermittent oxygen-depleted episodes in the PeriTethys and Paratethys. Palaeogeography, Palaeoclimatology, Palaeoecology 536, 1-16, https://doi.org/10.1016/j. palaeo.2019.109395. 